propinquo es, ac ibi multos notos propinquosque habes, minus hoc officium eximio viro, qui et tuum actum aliquando honorauit, detrectare conuenit. Decano autem Sanctase Gudulae ${ }^{1}$, qui eum istic comitari non recusavit, hospitium in aedibus meis apud Leousrdiam obtuli, ubi et te Igranus noster non grauitate (si forte eo uti voles) excipiet. Itsque aut tibi isthuc proficiscendum est, aut certe te excusstiones apud Reverendissimum Leousrdiensem conquirere decet cur illi in hoc officio non adsis.

A Folcardo fratre tuo litteras nuper accepi, \& quoniam earum pars ad te pertinet, hisce eas coniungere visum fuit. Vosque isthic rogo ut ad eum nonnunquam scribitis absentemque consolemini, ac ad complenda feliciter studia exhortemini. Do itinere antem Italico, de quo ille a me certior fieri cupit, ex domini Hopperi consilio statuam. Bene vale nepos charissime \& fratri coniugique ac amicis omnibus isthnc maltam salutem dicito. Bruxella, vii Decemb. 1569.

Tuus ex animo avunculus

VighIUS ZuICHÉmus.

\title{
VIII. Alfonso d'Este to Catherine de Médicis
}

Reggio, 18 Decomber 1574.

Letter of introduction for his brother from Alfonso II, duke of Ferrara (1533-97), who is remembered as the patron of Tasso. There is no answer to this letter in the Lettres de Catherine de Afddicis nor any allusion to it.

Holograph, in s fine Italian hand.

Alla Serme Regina madre del Re Christianissimo, Signora mia osservandissims.

Berma Sra mia osserma.

Il carissimo Fratre mio gentilhuomo presente esshibitore dopo haver fatto humilissima reverenza alla $M^{\text {ta }} \mathrm{v}$. in nome mio le esporra la cagione per la quale viene mandato da me supplicola a degnarti di vederlo et assoltarli un quella hamanita che e solita di fare ot a prestare a lui quella credenza che per benignita sua darebbe a me proprio et in questi raccomandandomi. ben humilimente nella desideratissima gratia della Mra $\nabla$. le bacio riverentemente la mano et prego il $\mathrm{G}^{3}$ dio che le doni ogni felicita. De Reggio a xviii di Decembre del LXXIIII.

D. V. Mt. Humillissimo et obedientissimo servitore

Alponso D'Este.

\section{Philip Marnix to Sidbrand Lubbertus}

Asperen, 22 September 1591.

Philip Marnix, lord of Sainte Aldegonde (1538-98), was, nert to William of Orange, the greatest of the early leaders of the Dutch revolt. His Beehive was an effeotive satire againgt the Roman ohurch. When Antwerp, of which he was burgomaster, was ceptured in 1585, he lost the confidence of his countrymen and retired from aotive lifo. (Seo Realencyllopadic fur protestartische Theologie und Kirche, s. v.)

Sidbrand Labbert (1558 or 1557-1625) was the first professor of theology at the Calvinist noiveraity of Franeker, founded in 1585 . He was a vigorous controversialist

1 At Brussels.

- Apparently a dialeotio form of 'fratello'. Alfonso had a brother who became cardinal of Ferrara and died in 1586. He may have had others.

- 'Grande.' 